\title{
The origin of samba in Brazil
}

It was in the Vargas Era that samba changed from a musical genre pursued to one of the most popular musical styles in our country. The popularization of samba in the cultural scene in Rio de Janeiro made the genre gain space in the Brazilian music industry. Thus, samba gained space and publicity on the radio.

Keywords: Samba; Popular Brazilian Music; It was Vargas.

\section{A origem do samba no Brasil}

Foi na Era Vargas que o samba passou de um gênero musical perseguido a um dos estilos musicais mais populares em nosso país. A popularização do samba no cenário cultural carioca fez com que o gênero ganhasse espaço na indústria musical brasileira. Assim, o samba ganhou espaço e divulgação no rádio.

Palavras-chave: Samba; Música Popular Brasileira; Era Vargas.

Topic: Cultura, Gênero e Subjetividade

Reviewed anonymously in the process of blind peer.
Received: 22/01/2021

Approved: 19/05/2021
Alberto Carlos de Souza (iD)

Universidade Federal do Espírito Santo, Brasil

http://lattes.cnpq.br/3806516459760480

http://orcid.org/0000-0002-5599-9400

acsouza71@bol.com.br
DOI: 10.6008/CBPC2674-6654.2021.001.0001
Referencing this:

SOUZA, A. C.. The origin of samba in Brazil. Humanum Sciences, v.3, n.1, p.1-13, 2021. DOI: http://doi.org/10.6008/CBPC26746654.2021 .001 .0001 


\section{INTRODUCTION}

Known as urban samba carioca or simply samba carioca, it is a Brazilian musical genre that originated among urban Afro-Brazilian communities in Rio de Janeiro in the early twentieth century. Having its roots in the cultural expression of West Africa and in Brazilian folk traditions, especially those linked to the primitive rural samba of the colonial and imperial period, it is considered one of the most important cultural elements in Brazil and one of the country's symbols. Present in the Portuguese language at least since the 20th century, the word "samba" was originally used to designate a "popular dance" or a "popular ballet". Over time, its meaning has been extended to a "similar circle dance

before the batuque "and also to a" genre of popular song ". This process of establishing itself as a musical genre began in the 1910s and had in the work "Pelo Telephone", launched by Odeon in 1917, its great inaugural landmark. Despite being identified by its creators, the public and the music industry as "samba", it was much more connected from the rhythmic and instrumental point of view to maxixe than to samba itself.

It was only at the end of the 1920s that samba was structured as it is modernly known. Having been born in the neighborhood of Estácio and soon extended to Oswald Andrade and other parts of the city through its railway branches, this samba brought innovations in rhythm, melody and also in thematic aspects. Its rhythmic change based on a new percussive instrumental pattern resulted in a more batucado and simcopato style - as opposed to the inaugural samba amaxixado - notably marked by a faster tempo, longer notes and a marked decay far beyond the simple palms used until then. The Statistic paradigm also innovated in the formatting of samba as a song, organized in first and second parts in both melody and lyrics. When creating a new reconfigured, structured and delimited musical reference, Estácio's samba dancers defined samba as a genre in a modern and finished way.

In this process of establishment as an urban and modern musical expression, samba from Rio de Janeiro had the decisive role of samba schools, responsible for defining and legitimizing definitively the aesthetic bases of rhythm, and radio, which greatly contributed to the diffusion and popularization of the genre and of your song interpreters. Thus, samba achieved great projection throughout Brazil and became one of the main symbols of the Brazilian national. Once criminalized and viewed with prejudice for its AfroBrazilian origins, the song genre has also won support among members of the most favored classes and the cultural elite of the country.

At the same time that it was established as the genesis of samba in Rio, the paradigm of Estácio's samba opened the way for its fragmentation, throughout the 20th century, into new subgenres and styles of composition and interpretation. Especially from the so-called "golden age" of Brazilian music, samba received abundant categorizations, some of which denote solid and well-accepted derivatives - such as bossa nova, pagode, high party, samba breque, samba-song. , the samba enredo and the terreiro samba - while other nomenclatures were somewhat more imprecise - such as samba in the watercress style, samba do noise, epistolary samba or phonetic samba - and some still merely derogatory - such as sambalada, sambolero or 
samba joia.

The urban samba in Rio has basically $2 / 4$ rhythm and varied tempo with conscious use of the needs of choruses, sung to the sound of clapping and beaten rhythm, in which one or more parts of declamation verses were added. Its traditional instruments are composed by percussion, tambourine, cuíca, tamborim, ganzá and surdo, to grant - whose inspiration is the choro - as the guitar and the cavaquinho. In 2007, Iphan declared samba from Rio de Janeiro and three of its matrixes - samba de terreiro, samba de festa-alto and samba de enredo - as cultural heritage in Brazil.

Its etmogolia is believed to be the first use of the word "samba" in the Brazilian press was in the Diario de Pernanbuco in 1830. The term was documented in the publication in a note against sending soldiers to the interior of Pernambuco as a disciplinary measure, because there they could be idle and entertained with "fishing of corrals [traps to catch fish], and climbing coconut trees, in whose pastimes the viola and samba will be welcomed". Another old appearance was recorded in the humorous Recife newspaper 0 Carapuceiro of 1838. In Rio de Janeiro, the word only came to be known at the end of the 19th century, when it was linked to rural festivities, to the universe of the black and to the "north" of the country, that is, the Brazilian Northeast.

For many years of colonial and imperial history in Brazil, the terms "batuque" or "samba" have been used in any manifestation of African origin that brought together dances such as umbigada, chants and uses of instruments by Africans. At the end of the 19th century, "samba" was referring to a "popular ballet" or different types of popular dances (xiba, fandango, catereté, cambomblé, Bahian) that assumed their own characteristics in each part of the country, not only due to the diversity of ethnic groups in the country. diaspora of Africa, as well as the peculiarity of each region in which they were based. In the 20th century, the term was gaining new meanings, such as a "fulia de batuque" and a "popular song genre". The first use of the word in the musical context would have been for "Em casa de baiana", from 1913, registered as "samba de festa-alto". Then, in the following year, for the works "The viola is hurt" and "vagabond boy". And, in 1916, a striking song was "Pelo Telephone", released as "carnival samba" and considered the founding landmark of urban samba in Rio. Samba Urbano Carioca had a black-based political and socio-cultural epicenter of Brazil in Rio de Janeiro that suffered a strong African influence. In the middle of the 19th century, more of the population of the cities as the capital - Portuguese Empire - was formed by slaves. At the beginning of this decade, Rio had more than half a million inhabitants, of which only half were born in the city, while the other part was closed from the old Brazilian provinces, mainly from Bahia.

In search of better living conditions, a large number of blacks from Bahia to Rio de Janeiro land increased considerably after the abolition of slavery. By the action of black Bahians living in Rio, new habits, customs and values of Afro-Bahian matrixes were introduced that influenced the culture of Rio, especially in popular events such as the traditional Festa da Penha and the carnival, The Black Women from Bahia and Recôncavo from Bahia, the Bahian aunts founded the Candomblé terreiros and disseminated the mysteries of the African-based religions of the Jeje-Nagô tradition in the city. In addition to the residences or the terreiros of the aunts of Bahia, they hosted various community activities, such as cooking and pagodas, where 
the urban samba in Rio would develop. Among the most well-known Bahian aunts in Rio, were the aunts Sadata, Bibiana, Fê, Rosa Olé, Amélia do Aragão, Veridiana, Mônica, Perciliana de Santo Amaro and Ciata. A place for meetings around religion, cuisine, dance and music, Tia Ciata's home was frequented by both samba dancers and influential intellectuals and politicians from Rio society.

Among some of his frequenters were Sinhô, pixiginha, Heitor dos Prazeres, João da baiana, Donga and Carminha, as well as some journalists and intellectuals, such as João do Rio, Manuel Bandeira, Mário de Andrade and Francisco Guimarães (popularly known as Vagalume).

Donga recorded the song "Pelo Telephone" where it became "carnival samba". The success of "Pelo telephone" marked the official start of samba. This primacy has, however, been questioned by some scholars, on the grounds that the work was only the first samba under this categorization to be successful. Before, "Em casa da baiana" was recorded by Alfredo Carlos Bricio, declared to the National Library as "samba de festaalto" in 1913, "A viola está magoada", by Paixão Cearence, released as "samba" by Baiano and Júlia the following year, and "Moleque vagabundo", "samba" by Lourival de Carvalho, also in 1914.

Another debate related to "Over the phone" concerns Donga's exclusive authorship, which was soon contested by some of his contemporaries who accused him of appropriating a collective, anonymous creation, registering it as his own. The central part of the song would have been conceived in the traditional improvisations in meetings at Tia Ciata's house. Sinhô claimed the authorship of the chorus "ai, se rolinha, sinhô, sinhô" and created another letter in response to Donga. However, Sinhô himself, who would consolidate himself in the 1920s, as the first great name of samba, was accused of appropriating other people's songs or verses - to which he justified himself with the famous maxim that samba was "like a bird" in the air, it is "whoever catches it first". This defense is part of a period in which the figure of the popular composer was not that of the individual who composed or organized sounds, but the one who registered and disseminated the songs. In the era of mechanical recordings, musical compositions - under the pretext of ensuring that there was no plagiarism - did not belong to the composers, but to the publishers and, later, to the record companies, a reality modified only with the advent of electrical recordings, when the right to property from the author of the work became individual and inalienable to the composer.

In any case, it was from "Pelo Telephone" that Donga's samba gained notoriety as a product in the Brazilian music market. Gradually, the nascent urban samba was gaining popularity in Rio de Janeiro, especially in the Festa da Penha and in the arnaval. Celebrated in October, the Festa da Penha became the great event for composers from Cidade Nova who wanted to publicize their compositions in the expectation that they would be released at the following carnival. Aracy Cortês as one of the first successful singers of the new genre of popular song.

The head of the revelry

Send me a message on the phone

That with joy

Don't question yourself to play

Ouch, ouch, ouch

It is to leave hurts behind, $\mathrm{O}$ boy 
Ouch, ouch, ouch

Be sad if you are able and you will see

I hope you get it

Not to do it again

Taking love from others

Then do your spell

Oh, if the dove, donkey, donkey

Got embarrassed, man, man

Is that the bird, sinhô, sinhô

Never sambou, donkey, donkey

Because this samba, sinhô, sinhô

Chilling, donkey, donkey

Put a wobbly leg, shank, shank

But make it come, sir, sir

Peru told me

If the Bat saw

Do not do nonsense

That I then left

This weirdness

of said-no-said

Ah! ah! ah!

There is the ideal, triumphant corner

Ouch, ouch, ouch

Live our unrivaled carnival

If the one who takes the love of others

For God to be punished

The world was empty

And the inhabited hell

Do you want it or not, donkey, donkey

Come to the cord, donkey, donkey

It is to be reveler, donkey, donkey

From the heart, donkey, donkey

Because this samba, sinhô, sinhô

Chilling, donkey, donkey

Put on a tight leg, shank, shank

But make it come, sir, sir

Who is good at taste

Show willingness

Don't look for backrest

Have laughter put

Make the face happy

No heartbreak

Ouch, ouch, ouch

Dance the samba

With heat, my love

Ouch, ouch, ouch

Because who dances

There is no pain or heat 
The solidification of the electric recording system made it possible for the recording industry to launch new sambas by singers with less powerful voices, such as Carmem Miranda and Mário Reis, performers who became references when creating a new way of interpreting the most natural and spontaneous samba, without so many ornaments, as opposed to the tradition of operatic blessing. These recordings followed an aesthetic pattern marked by structural similarities to the lundu and, mainly, to the maxixe. Because of this, this type of samba is considered by scholars as "Samba-maxixe" or "samba amaxixado". Although the samba practiced in the festivities of the Bahian communities in Rio was an urban stylization of the ancestral "Samba de Roda" from Bahia, characterized by a samba of the high party with refrains sung to the marked rhythm of the palms and the plates shaved with knives, this samba it was also influenced by the gherkin. It was in the following decade that a new model of samba would be born, from the hills of Rio de Janeiro, quite distinct from that of the amaxix style associated with the communities of Cidade Nova.

It was the urban samba and the samba of Estácio that in this scenario that would be born during the second half of the 1920s, a new type of samba, called "samba do Estácio", that would constitute the genesis of urban samba in Rio de Janeiro creating a new pattern as revolutionary that its innovations last until today. Located near Praça Onze and housing the Morro de São Carlos, the neighborhood of Estácio was a center of convergence of public transportation, mainly of cable cars that served the North Zone. Its proximity to the nascent hills as well as its primacy in the formation of this new samba ended up linking its musical production, starting from urban trains, to the favelas and suburbs of Rio de Janeiro, such as Moura da Mangueira and the suburban neighborhood of Oswaldo Cruz. Estácio's samba was distinguished from Cidade Nova's samba both in thematic aspects, as well as in the melody and rhythm.

\section{THEORETICAL DISCUSSION}

Made for the parades of the carnival blocks in the neighborhood, the Estaciano samba innovated with a faster tempo, longer notes and a cadence beyond the traditional palms. Another structural change resulting from this samba was the valorization of the "second part" of the compositions: instead of using the typical improvisation of the samba circles of the high party or the carnival parades, there was the consolidation of pre-established sequences, which would have a theme - for example, everyday problems and the possibility of fitting everything within the standards of phonographic recordings of the time. In comparison to the works of the first generation of Donga, Sinhô and company, the sambas produced by Estácio's group also stood out that can be evidenced in a testimony by Ismael Silva about the innovations introduced by him and his companions in the new urban samba in Rio:

[...] It's just that when I started, the samba of that time was not enough for the carnival groups to walk on the street as we see today. There was no walking style. I started to notice that there was this thing. Samba was like this: tan tantan tan tantan. It was not possible. How would a block get out on the street like that? Then, we started making a samba like this: bum bum paticumbum pugurumdum.

Thus, at the end of the 1920s, the modern carioca samba had two distinct models: the primitive urban samba of Cidade Nova and the new syncopated samba of the Estácio group. However, while the Bahian 
community enjoyed a certain social legitimacy, including the protection of important personalities from Rio society who supported and attended the African musical circles, the new Stacian samba dancers suffered sociocultural discrimination, including through police repression. The popular neighborhood and with a large contingent of blacks and mulattos, Estácio was one of the great strongholds of poor samba dancers situated between marginality and social integration, who ended up being stigmatized by Rio's upper classes as vagrants as "dangerous". Because of this pecha, the Estaciano samba suffered great social prejudice in its origin. To avoid police harassment and gain social legitimacy, Estácio's samba dancers decided to link their batucadas to the carnival samba and organized themselves in what they christened as Schools of Sambas, as said by Ismael Silva:

[...] With the carnival over, samba continued because we did samba all year. At Café Apolo, at Compadre's café, across the street, at the fish stews we used to make at friends' houses, at the backyard feijoadas or at dawn, on street corners and in bars. Then the police came and bothered. But it didn't bother the Amor people (carnavalesco ranch), who were thirsty and took leave. And people with a lot of envy. In 1927, more or less October, we decided to organize a block, even without a license, that could allow us to go out at the carnival and do samba all year round. Organization and respect, without fights or huffing, were important. It was called "Let Falar" as an embarrassment to the comadres of the neighborhood's middle class, who used to call people a vagabond. We were baddies, in a good way, but bums weren't.

Although the primacy of the first samba school in the country is contested by the training centers of Portela and Mangueira, Deixa Falar was a pioneer in spreading the term in its quest to establish an organization different from the carnival blocs of that time [141] and also the first carnival association to use the ensemble in the future known as drums, a unit composed of percussion as deaf, tambourines and cuícas, which - when joining the already used tambourines and chucalhos - gave a more "march" to the samba of the parades.

Another reason for the success of Estaciano samba in the music market was the introduction of the "second part", which stimulated the establishment of partnerships between composers. For example, one composer created the chorus of a samba and another composer conceived the second part, as was the case with the partnership between Ismael Silva and Manuel Rosa in "Para Me Livrar do Mal", the result of the first part of the Sambista and the second part of samba dancer from Vila Isabel. With the growing demand for new sambas by the interpreters, the practice of buying and selling compositions has also become common.

This transaction normally took place in two different ways: the author negotiated the sale of only the samba recording, that is, the samba player remained as the author of the composition, but would not receive any part of the gains obtained from the sales of the records, which were divided between the buyer and the record company or the entire composition, that is, the samba player completely lost the rights to his samba, including authorship. In some cases, the sambista sold the partnership to the buyer and also received a portion of the profits from the sales of the records. Selling a samba meant the samba player had a chance to see his production publicized - especially when he did not yet enjoy the same prestige acquired by the first generation samba dancers - and also a way to make up for his own financial difficulties. For the buyer, it was the possibility to renew his repertoire, record more records and earn sales, and further consolidate his artistic 
career. Artists with good contact with record labels, the popular interpreters Francisco Alves and Mário Reis were adepts of this practice, having acquired sambas from composers such as Cartola and Ismael Silva.

Thus, Hall (2006) understands that in this moment in which we live, marked by globalization, the identity crisis is inevitable. Such a state of crisis allows the subjects new positions of identification, making identities less fixed and unified, but open to the new, without giving up their culture, enabling the learning of new knowledge, in this irreversible process - called globalization -, open to diversity . Thus, we understand that it is the function of the school to create with the students a space for valuing their cultural heritage and for that, we consider the theory of places of memory - proposed by Nora (1984).

The theory of places of memory was formulated and developed based on the seminars given by Nora at the École Pratique de Hautes Etudes, in Paris, between 1978 and 1981, being published in "Les Lieux de Mémorie", a work composed of four volumes. Referring to French national memory, Nora, in this work, considers it important to inventory the places where memory - which is increasingly threatened with disappearing - still remains incarnated.

The concept of places of memory, as conceived by Nora (1992), was the guiding thread of the report. The theory of Places of Memory was formulated from the seminars held by Pierre Nora between 1978 and 1981, at the École Pratique des Hautes Études - in Paris. From 1984, under his direction, the edition of "Les lieux de mémoire" began, a work that, based on the observation of the rapid disappearance of French national memory, proposed the inventory of places where it actually remained incarnated, thanks to the men's will and despite the passage of time. For Pierre Nora (1992) symbols, traditional music, parties, emblems, monuments, celebrations, praises, dictionaries and museums are places of memory.

The idea of heritage is confused with that of legitimate law. The bibliography of science that aims to study the material and spiritual culture of a people is full of examples of cultures, in which material goods are not characterized as objects separate from their owners. These products do not always have a utility symbol. In some cases, they serve manual purposes, but at the same time they absorb magical-religious and social meanings, which have been called "total social facts". However, these goods, of an economic, moral, religious, magical, political, legal, aesthetic, psychological and physiological nature. They integrate, in some way, moral extensions of their owners, and these, in turn, are inseparable parts of social and cosmic totalities that go beyond their condition as individuals.

In relation to culture, Laraia (2005) concludes that,

[...] each cultural system is always changing. Understanding this dynamic is important to mitigate the shock between generations and to avoid prejudiced behavior. In the same way that it is fundamental for humanity to understand the differences between people of different cultures, it is necessary to know how to understand the differences that occur within the same system. (LARAIA, 2005)

It is also necessary to consider that in the current pedagogical conception, there is an indissolubility between education and culture,

It needs to start from the potential of the student and motivate him [...] because education as a training and an instrument of participation is its own creativity. Culture constitutes the proper context of education, because it is a fundamental motivation for community mobilization and a concrete framework for historical creativity (DEMO, 1993, p. 58). 
A 1932 Vargas decree regulating radio advertising was crucial to the commercial, professional and popular transformation of Brazilian broadcasting. With the authorization that ads could occupy 20\% (and then $25 \%$ ) of the programming, the radio became more attractive and safe for advertisers and - added to the increase in sales of receiver devices in the period - transformed the vehicle of its function once educational for an entertainment powerhouse. With the contribution of financial resources from advertising, the broadcasters began to invest in musical programming, turning the radio into the great popularizer of popular music in the country - whether recorded on disc or presented live directly from the stations' auditoriums and studios. With samba as a great attraction, the radio gave space to the genre with the "carnival sambas", released for carnalalescas parties, and the "mid-year sambas", launched throughout the year.

From this scenario, radio broadcasters Ademar José (in Rio) and Cesar Ladeira (in São Paulo) stood out, as pioneers in the establishment of exclusive contracts with singers for presentation in live programs. That is, instead of receiving only one fee per presentation, the monthly remuneration was fixed, a model that triggered a fierce dispute between radio stations, including from different states, to form their professional and exclusive casts with popular stars of popular music. and philharmonic orchestras Great samba interpreters, like the notable little Carmen Miranda, started to sign advantageous contracts to act exclusively with a certain radio station. We are the radio singers, we live life singing.At night we rock your sleep, in the morning we will wake you up

We are the radio singers, our songs crossing the blue space Hearts from North to South gather in a great embrace.

Singing across spaces

I sow songs, giving joy to those who cry

(boom, boom, boom, boom, boom)

I sing because I know my song

will dispel the sadness that lives in your heart

We are the radio singers, we live life singing

At night we rock your sleep,

in the morning we will wake you up

We are the radio singers,

our songs crossing the blue space

Hearts from North to South gather in a great embrace.

I sing to see you more content

because the happiness of others is our joy

(boom, boom, boom, boom, boom)

I sing and I'm happy just like that

Now I ask you to sing

a little bit for me.

The institution of large auditorium programs created the need to set up large radio orchestras, conducted by arranging conductors, which gave a more sophisticated look to Brazilian popular music. One of the most notorious orchestral formations on the radio was the Brazilian Orchestra - under the command of maestro Ramisés Gnatalli and with a team of musicians such as the samba dancers João da Baiana, Bide and Heitor dos Prazeres in percussion -, which combined standards of the international song of the time with popular instruments in Brazilian music, such as the cavaquinho and the guitar. The Brazilian Orchestra was 
notable for the success of the program Um million melodies, by Rádio Nacional Carioca, one of the most popular in the history of Brazilian radio.

The consolidation of samba as the flagship of the radio programming of Rio de Janeiro was marked by the association of the musical genre with the image of white artists, who, even when proletarianized, were more palatable to the average taste of the public, while the poor black samba player remained normally on the margins of this process as a mere supplier of compositions for the great white performers or as instrumentalists accompanying them. This strong presence of white interpreters and composers was also decisive for the acceptance and appreciation of samba by the country's economic and cultural elites. From this, the middle class started to recognize the value of the rhythm invented by black Brazilians. The Municipal Theater of the federal capital became the stage for elegant carnival balls attended by the elite of Rio. Having contact with the popular genre through samba and choro circles, the renowned conductor Heitor Villa-lobos promoted a musical meeting between the samba dancers Cartola, Zé da Zilda, Zé Espinguela, Pixinguinha, Donga, João da Baiana and others, on the ship Uruguay, anchored at the pier Mauá in 1940. The result of the recordings was published in the United States on several other discs.

The construction of national identity Having acted decisively for the growth of radio in Brazil, in the Vargas Era, he perceived samba as the construction of this idea, especially under the Estado Novo, whose ideological cultural policy of re-conceptualizing the popular and extolling everything that was considered an authentic national expression, samba was elevated to the position of great national symbol of the country and the official rhythm of the country. However, one of the concerns of the Vargas regime was to interfere in musical production in order to promote samba as a means of "pedagogical" socialization, that is, by banning compositions that defied the ethics of the regime. In this quest to "civilize" samba came into action political bodies such as the Agency and Propaganda Department (DIP) to order sambas that exalt work and censor lyrics that deal with bohemia and rascalism, two of the most common themes in the tradition of Rio's urban samba. Musical contests were also instituted through which public opinion elected its favorite composers and performers.

Under Vargas, samba had an expressive weight in the construction of an image of Brazil abroad and was an important means of cultural and tourist dissemination of the country. In an attempt to reinforce a positive national image, the presence of renowned interpreters of the kind in presidential committees to Latin American countries has become frequent. At the end of 1937, the samba dancers Paulo da Portela and Heitor dos Prazeres participated in a caravan of Brazilian artists to Montevidel that performed at the Gran Exposición Feria Internacional del Uruguay. The Brazilian government also financed an information and popular music program called "Uma Hora do Brasil", produced and broadcast by Radio El Mundo, from, which had less irradiation to Nazi radiation to Buenos Aires. When the Vargas regime approached the United States, DIP made an agreement to broadcast Brazilian radio programs on hundreds of CBS network stations Under this context, the samba "Aquarela do Brasil" (by Ary Barroso) was launched in the United States market, becoming the first Brazilian musical success abroad and one of the most popular works of the national popular songbook.] In the midst of the neighborhood policy, Walter Disney visited Portela during his visit to 
Brazil in 1941, whence the hypothesis that Zé Carioca, a character created by the cartoonist to express the Brazilian way, would have been inspired by the figure of the samba player Paulo Portela.

Brasil

Meu Brasil Brasileiro

Meu mulato inzoneiro

Vou cantar-te nos meus versos

Meu Brasil samba queda bamboleio

Que faz gingar

Oh Brasil do meu amor

Terra de nosso senhor

Brasil, Brasil

Brazil

Where hearts were entertaining June

We stood beneath an amber moon

And softly murmured someday soon

Brazil, Brazil

We kissed and clung together

Then

Tomorrow was another day

The morning found me miles away

With still a milion things to say

Now as twilight beams in skies above

Recalling all the thrills of love

There is one thing I'm certain of

Return I will

To old Brazil

The rise of samba as a popular musical genre in Brazil also relied on its dissemination in Brazilian cinema, especially in musical comedies, being an integral part of soundtracks, the plot or even the main theme of the cinematographic work. The good public acceptance with the short film "Voz do Carnaval", paved the way for several other cinematographic works related to rhythm, many of which had a strong presence of radio idol interpreters in the cast, such as Álô Alô Brasil ", which had sisters Carmen and Aurora Miranda, Francisco Alves, Mário Reis, Dircinha Batista, Bando da Lua, Almirante, Lamartine Babo, among others. The advent of the popular chanchada films made Brazilian cinema one of the biggest promoters of carnival music. However, over the course of the decade, the samba of the Rio de Janeiro samba was losing space on Brazilian radio to new subgenres that were being formed, while figures like Cartola and Ismael Silva were ostracized until they left the music scene in the late 1940s.

\section{CONCLUSONS}

In general, the samba-song was marked as a slower tempo variant, with a dominance of the melodic line over the rhythmic marking that basically explores the theme of subjectivity and feeling. As their releases took place outside the carnival season, the strand was linked to the so-called "mid-year samba". However, during the 1930s, the term samba-song was used to arbitrarily designate many compositions contained in that designation of "mid-year samba", but which were not yet samba-songs themselves, [234] whether they are more saddened by more lively. On the other hand, many sambas at the time of its release would later be 
recognized as samba-song, as in the case of works by Ary Barroso and Noel Rosa Not by chance, Zuza Homem de Mello and Jadir Severiano consider that the style was truly inaugurated with the second version of the song "rancho fundo", with melody by Ary Barroso and lyrics by Lamartine Babo.

Basically, Carnival was reserved for the launch of marchinhas and sambas de enredo, a variant typified in this way in the 1930s because of the lyrics and melody, which must comprise the poetic summary of the theme chosen by the samba school for its carvavalesco dedfile. Unlike samba-enredo, terreiro samba or also court samba, it was a short-tempo samba modality, with the second most measured part that prepares the drums' turn for a more lively return to the beginning. Its format was also consolidated in the 1930s.

Also from that time, samba choro - at first called choro-song or choro sung - was a syncopated hybrid strand of samba with the instrumental choro, but with medium tempo and presence of lyrics. Created by the Brazilian phonographic industry, it was launched, with all indications, with "Love in excess", by Gadé and Falfredo Silva, in 1932. One of the most popular sambas of this variant is "Carinhoso", by Pixiguinha, released as choro in 1917 , received lyrics and ended up relaunched two decades later, in the voice of Orlando Silva, with great commercial success. In the following decade, the cavaquinista Waldir azevedo would popularize the chorinho, a kind of instrumental samba of fast tempo.

\section{REFERENCES}

ALBIN, R. C.. The golden book of MPB: the history of our popular music from its origins to today. Rio de Janeiro: Ediouro, 2003.

ALENCAR, E.. Our Sinhô do Samba. Rio de Janeiro: Funarte, 1981.

ALVARENGA, O.. Popular Brazilian Music. Porto Alegre: Globo, 1960.

BENCHIMOL, J. L.. Pereira Passos: a tropical Haussmann; the urban renewal of the city of Rio de Janeiro at the beginning of the 20th century. Rio de Janeiro: Municipal Secretariat for Culture, Tourism and Sports, 1990.

BOLÃO, O.. Batuque Is A Privilege. Rio de Janeiro: Lumiar, 2009.

CABRAL, S.. The samba schools in Rio de Janeiro. Rio de Janeiro: Lumiar, 1996.

CABRAL, S.. MPB in the radio era. São Paulo: Moderna, 1996.

CALDEIRA, J.. The construction of samba. São Paulo: Mameluco, 2007.

CANDEIA FILHO, A.; ARAUJO, I.. Escola de Samba: tree that forgot the root. Rio de Janeiro: Lidador, 1978.

CARDOSO JÚNIOR, A.. Carmen Miranda: The singer from Brazil. São Paulo: Author's private edition, 1978.

CARNEIRO, E.. Anthology of the Brazilian Negro. Rio de Janeiro: Act, 2005.
CASTRO, M. B.. Zicartola: memories of a samba house. São Paulo: Itaú Cultural, 2016.

CASTRO, R.. The night of my good. São Paulo: Companhia das Letras, 2015.

DOMINGUES, H. F.. In the Time of Noel Rosa. 2 ed. Rio de Janeiro: Livraria Francisco Alves, 1977.

EFEGÊ, J.. Figures and Things of Brazilian Popular Music. 2 ed. Rio de Janeiro: Funarte, 2007.

FERNANDES, N. N.. Samba schools: celebrant subjects and celebrated objects. Rio de Janeiro: Carioca Memory Collection, 2001.

FERRARETTO, L. A.. Radio: the vehicle, history and technique. Porto Alegre: Sagra Luzzatto, 2001.

FRANCESCHI, H. M.. The Edison House and its time. Rio de Janeiro: Sarapui, 2002.

FRANCESCHI, H. M.. Estácio's samba samba: 1928 to 1931. São Paulo: Instituto Moreira Salles, 2010.

FLEET, W. N.. Luxurious assistance: Samba national symbol, Noel Rosa generation and cultural industry. São Paulo: Anna Blume, 2003.

GARCIA, T. C.. Carmen Miranda's "green and yellow it" (1930-1946). São Paulo: Anna Blume, 2004.

GARCIA, W.. Bim Bom: João Gilberto's conflict-free contradiction. São Paulo: Peace and Earth, 1999. 
GIRON, L. A.. Mario Reis: The fine samba. São Paulo: Publisher 34, 2001.

GOULART, S.. Under the Official Truth: Ideology, Propaganda and Censorship in the Estado Novo. São Paulo: Ground Zero, 1990.

GUIMARÃES, F.. At the samba wheel. Rio de Janeiro: Funarte, 1978.

RAMOS, F.; MIRANDA, L. F.. Cinédia. In: Encyclopedia of Brazilian Cinema. São Paulo: Senac, 1997.

LOPES, N.. Brazilian encyclopedia of the African diaspora. Rio de Janeiro: Black Seal, 2004.

LOPES, N.. New Banto Dictionary from Brazil. Rio de Janeiro: Pallas, 2012.

LOPES, N.. High party: samba de bamba. Rio de Janeiro: Pallas, 2005.

LOPES, N.; SIMAS, L. A.. Dictionary of Social History of Samba. 2 ed. Rio de Janeiro: Brazilian Civilization, 2015.

LOPES, N.. The wide and diverse universe of samba. In: STROETER, G.; MORI, E.. A tree of Brazilian music. São Paulo: Sesc, 2019.

MACEDO, M. J.. Notes for a History of Black Dances in São Paulo. In: BARBOSA, M.; RIBEIRO, E.. Balls: Soul, SambaRock, Hip Hop and Identity in São Paulo. São Paulo: Quilombhoje, 2007.

MARCONDES, M. A.. Encyclopedia of Brazilian music: classical, folk and popular. 21 ed. São Paulo: Art, 1977.

MÁXIMO, J.; DIDIER, C.. Noel Rosa: A Biography. Brasília: UnB, 1990.

MELLO, Z. H.; SEVERIANO, J.. The Song in Time - Volume 1. São Paulo: 34, 1997.

MELLO, Z. H.; SEVERIANO, J.. The Song in Time - Volume 2. 6 ed. São Paulo: 34, 2015.

MELLO, Z. H.. Encyclopedia of Brazilian Music Samba and Choro. São Paulo: Publifolha, 2000.

MENDES, R.; JÚNIOR, W.. Chula: Behavior translated into song. Salvador: ADM Foundation, 1976.

MOTTA, N.. Tropical Nights. Rio de Janeiro: Objective, 2000.

MOURA, R.. Aunt Ciata and little Africa in Rio de Janeiro. Rio de Janeiro: Funarte, 1983.

MUNIZ JUNIOR, J.. From Batuque to the samba school. São Paulo: Symbol, 1976.

SHIPS, S. C.. From bossa nova to tropicália. 2 ed. Rio de Janeiro: Zahar, 2004.
NETO, L.. A history of samba: The origins. São Paulo: Companhia das Letras, 2017.

PEREIRA, C. A. M.. Cacique de Ramos: A History that gave Samba. E-Papers, 2003.

RUIZ, R.. Araci Cortes: beautiful flower. Rio de Janeiro: Funarte, 1984.

SABINO, J.; LODY, R. G. M.. African matrix dances: anthropology of the movement. Rio de Janeiro: Pallas, 2011.

SADIE, S.. Grovede music dictionary: concise edition. Rio de Janeiro: Zahar, 1994.

SANDRONI, C.. Decent spell: transformations of samba in Rio de Janeiro, 1917-1933. Rio de Janeiro: Zahar, 2001.

SAROLDI, L. C.; MOREIRA, S. V.. National Radio: Brazil in tune. 2 ed. Rio de Janeiro: Zahar, 2005.

SEVERIANO, J.. A history of Brazilian popular music: from its origins to modernity. São Paulo: 34, 2009.

SILVA, M. T. B.; OLIVEIRA FILHO, A. L.. Top hat, the times gone. 2 ed. Rio de Janeiro: Gryphus, 1998.

SODRÉ, M.. Samba, the owner of the body. Rio de Janeiro: Mauad Editora Ltda., 1998.

SOUZA, T.. There's more samba: from roots to electronics. São Paulo: 34, 2003.

TATIT, L.. The songwriter: songwriting in Brazil. São Paulo: Edusp, 1996.

TINHORÃO, J. R.. Social History of Brazilian Popular Music. Lisbon: Editorial Path, 1990.

TINHORÃO, J. R.. Popular Music: A Debate Theme. São Paulo: Publisher 34, 1997.

TINHORÃO, J. R.. Samba now goes: the farce of Brazilian music abroad. Rio de Janeiro: JCM, 1969.

TINHORÃO, J. R.. Short History of Popular Music (from Modinha to Protest Song). Petrópolis: Voices, 1974.

VASCONCELOS, A.. Panorama of Brazilian Popular Music at the Belle Époque. São Paulo: Livraria Santanna, 1977.

VELLOSO, M. P.. Culture and political power in the Estado Novo: a configuration of the intellectual field. In: Estado Novo: ideology and power. Rio de Janeiro: Zahar, 1982.

VIANNA, H.. The Mystery of Samba. 21 ed. Rio de Janeiro: Zahar, 1995.

WISNIK, J. M.. Some issues of music and politics in Brazil. In: BOSI, A.. Brazilian culture, themes and situations. São Paulo: Attica, 1987.

A CBPC - Companhia Brasileira de Produção Científica (CNPJ: 11.221.422/0001-03) detém os direitos materiais desta publicação. Os direitos referem-se à publicação do trabalho em qualquer parte do mundo, incluindo os direitos às renovações, expansões e disseminações da contribuição, bem como outros direitos subsidiários. Todos os trabalhos publicados eletronicamente poderão posteriormente ser publicados em coletâneas impressas sob coordenação da Sapientiae Publishing, da Companhia Brasileira de Produção Científica e seus parceiros autorizados. Os (as) autores (as) preservam os direitos autorais, mas não têm permissão para a publicação da contribuição em outro meio, impresso ou digital, em português ou em tradução. 